Research Article

\title{
New record of Satyrichthys milleri Kawai, 20 I 3 (Peristediidae) from Gulf of Mannar, Bay of Bengal
}

\begin{abstract}
A specimen of Satyrichthys milleri Kawai, 2013 with the standard length of $221 \mathrm{~mm}$ was collected from Tuticorin fishing harbour, south east coast of India on 23rd October 2014. It was collected by bottom trawlers at a depth ranges from $200-250 \mathrm{~m}$. This is the first attempt to provide a detailed description of the species from the Gulf of Mannar. This record was compared with the first reported specimen in order to compare the external morphology with known specimen. The present study constitutes an extension of the known distributional range of this species from the Andaman to the Gulf of Mannar.
\end{abstract}

Keywords: Fishing harbor, Trawler, Depth, Range extension, Gulf of Mannar
Volume 5 Issue $6-2017$

\author{
Kannan K,' Ajith kumar TT, ${ }^{2}$ Zacharia PU, ${ }^{3}$ \\ Joshi $\mathrm{KK}^{3}$ \\ ITRC of Central Marine Fisheries Research Institute, India \\ ${ }^{2}$ National Bureau of Fish Genetic Resources, India \\ ${ }^{3}$ Central Marine Fisheries Research Institute, India
}

Correspondence: Kannan K, Research Scholar,TRC of Central Marine Fisheries Research Institute, India, Tel 91 9790155073, Email kanna.k84@gmail.com

Received: December 0I, 2016 | Published: June 29, 2017

\section{Introduction}

The scorpaeniform armoured sea robin (Peristediidae) generally, the entire genus from deep waters of tropical and temperate oceans of the world, the depths ranging from about 50 to $800 \mathrm{~m} .{ }^{1,2}$ Peristediidae characterized by a body entirely enclosed by four rows of spinous bony plates (scutes) on each side and a large bony head with spines and ridges; each first infraorbital (lacrymal) anteriorly extending in distinct rostral projections; barbels on the lower jaw and pectoral fins with the two ventral most fin rays free and enlarged. ${ }^{1-3}$

About 33 peristediidae species in six genera (Gargariscus Smith 1917, Heminodus Smith 1917, Paraheminodus Kamohara 1958, Peristedion Lacepede 1801, Scalicus Jordan 1923 and Satyrichthys Kaup 1873). ${ }^{1}$ Kawai $^{1}$ revised the genus-level classification of the armored sea robins in a comprehensive study on the phylogeny of peristediid fishes and separated the two closely related genera Satyrichthys and Scalicus.

The Indo-Pacific genus Satyrichthys Kaup, $1873^{1}$ are characterized by their lack of upper jaw teeth, possession of a smooth lateral margin of the head, posterior bony plates in the lower lateral rows separated on the ventral midline, no branched barbels on the lower jaw except for the posterior-most lip and chin barbels and fewer than 20 soft rays in the dorsal and anal fins. ${ }^{1,2}$ In his recent review of the genus Satyrichthys recognizes seven species: Satyrichthys was revised by Kawai ${ }^{2}$ who found seven valid species Satyrichthys moluccensis, Satyrichthys laticeps, Satyrichthys Rieffeli, Satyrichthys Welchi, Satyrichthys Clavilapis, Satyrichthys Longiceps and Satyrichthys Milleri. ${ }^{2}$ The report of $S$. milleri described in the present study is the first documentation for Tuticorin coast, Gulf of Mannar.

\section{Materials and methods}

Satyrichthys milleri was collected from Tuticorin fishing harbour, Gulf of Mannar On 23rd October 2014 from the by-catch landed by deep sea trawler. The specimen was caught approximately $50 \mathrm{Km}$ east of Tuticorin ( $8^{\circ} 44^{\prime} 46.97^{\prime \prime} \mathrm{N}$ and $\left.78^{\circ} 37^{\prime} 24.10^{\prime \prime} \mathrm{E}\right)$ in Gulf of Mannar at a depth of 200-250m (Figure 1).

\section{Measurements and Counts}

The specimens were injected with $5 \%$ formalin and brought to the laboratory in containers filled with $5 \%$ formalin for detailed examination. The morphometric character of the specimen was measured with a digital vernier calliper with an accuracy of $0.1 \mathrm{~mm}$ by Kawai et al. ${ }^{4}$

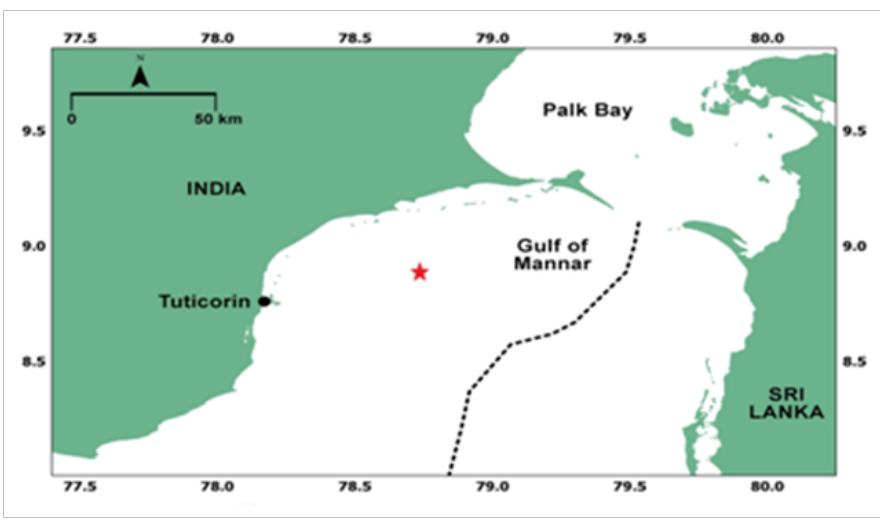

Figure I Study Area (red).

\section{Result}

\section{Description}

Body fusiform covered with bony plates; Head large depressed and extremely expanded around lateral edges; Mouth large, inferior; Posterior tip of upper jaw not reaching to below anterior border of orbit, lower jaw reaching below anterior border of orbit and jaws; vomer and palatine toothless; Flat and triangular rostral projections on both sides being parallel, length as long as its width at base. No rostral, small and stout post temporal spine with ridge. Longitudinal ridge are running from preopercle to rostral projection; Two opercular spines one uppermost smaller and lowermost larger with a ridge. Gill rakers on the first arch resemble a stick with minute spines on inner side (Figure 2A). The morphometric characters and meristic counts of the collected specimens were taken and compared with existing specimens were shown in Table 1.

\section{Barbels}

Barbels present on the lip and chin; in lips three unbranched barbels on the anterior side and single long branched barbels on the posterior side; four unbranched on chin (Figure 2B). 


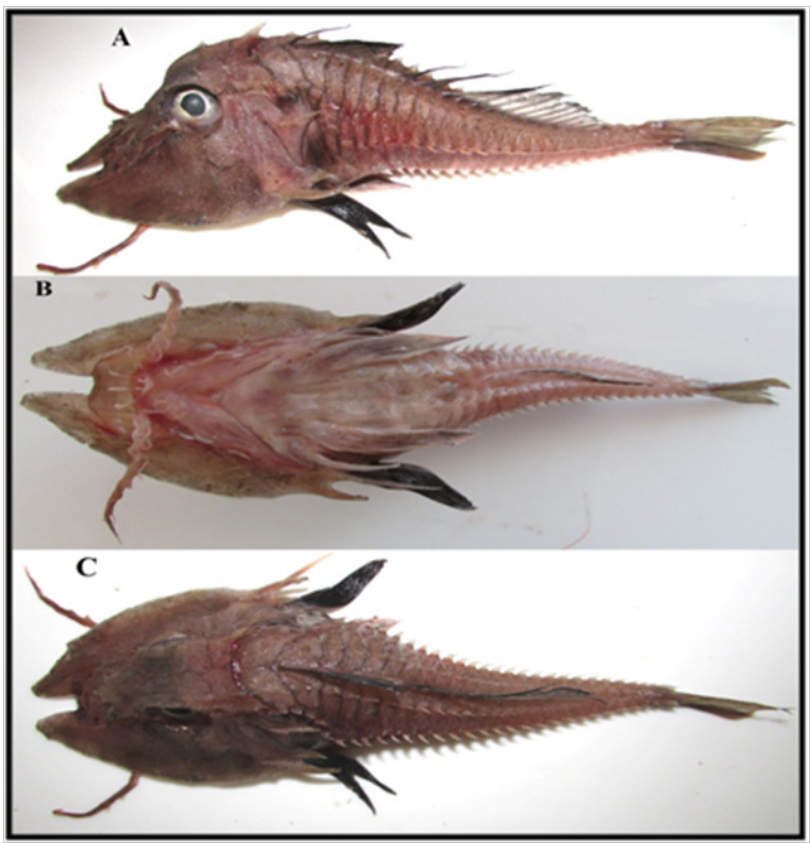

Figure 2 Side (A),Ventral (B) and Dorsal (C) view of Satyrichthys milleri from Gulf of Mannar.

Table I Morphometric and meristic characters of Satyrichthys milleri off Gulf of Mannar

\begin{tabular}{llll}
\hline Characters (mm) & & SL \% & Kawai, 20 I3 \\
\hline Standard Length & 221.22 & - & $59.9-265$ \\
Body Depth & 45.02 & 20.35 & $20.3-27.2$ \\
Body Width & 26.18 & 11.83 & $11.8-19.6$ \\
Head Length & 95.44 & 43.14 & $41.8-49.3$ \\
Head Depth & 44.89 & 20.29 & $20.3-25.9$ \\
Head Width & 76.28 & 34.48 & $34.8-47.2$ \\
Distance from Snout to Dorsal Fin & 90.54 & 40.92 & $40.8-47.7$ \\
Distance from Snout to Anal Fin & 118.03 & 53.35 & $54.1-60.6$ \\
Distance from Snout to Anus & 104.12 & 47.06 & $47.7-53.5$ \\
Snout Length & 46.58 & 21.05 & $21.0-24.1$ \\
Rostral Projection Length & 16.45 & 7.43 & $7.5-10.6$ \\
Longest Barbel Length & 66.13 & 29.89 & $30.4-45.2$ \\
Upper Jaw Length & 28.97 & 13.09 & $13.7-17.5$ \\
Lower Jaw Length & 35.01 & 15.82 & $15.4-19.3$ \\
Orbital Diameter & 18.58 & 8.39 & $8.7-13.2$ \\
Inter Orbital Width & 19.73 & 8.91 & $9.0-11.9$ \\
Pectoral Fin Length & 47.02 & 21.25 & $16.2-22.4$ \\
Length of Upper Detached Pectoral Fin Ray & 34.12 & 15.42 & $18.2-24.9$ \\
Length of Lower Detached Pectoral Fin Ray & 44.61 & 20.16 & $14.7-20.7$ \\
Pelvic Fin Length & 43.82 & 19.8 & $21.3-27.1$ \\
Length of First Dorsal Spine & 20.99 & 9.48 & $8.1-12.9$ \\
Caudal Peduncle Length & 25.15 & 11.36 & $11.0-14.2$ \\
Caudal Peduncle Depth & 10.6 & 4.79 & $3.2-4.2$ \\
\hline
\end{tabular}

\section{Bony plates}

Body bony plates arranged in four horizontal rows, each plate with one sharp backwardly directed spine. The dorsal rows reached up to caudal peduncle, anterior most bony plate in dorsal row largest and ventral row ends before the anus; Anterior five bony plates in upper lateral row small; no plates with a small forwardly directed spine; Lower lateral row terminating on caudal peduncle (Figure 2A \& 2C).

\section{Fins}

Dorsal fin originates between first and second bony plates in dorsal row end and on anterior portion of caudal peduncle. Anal fin originating posterior to anus; Pectoral fin reaching to base of first anal fin ray; lower two rays completely free and greatly thickened, upper ray longer than lower. Pelvic fins reaches up to anus; caudal fin weakly emarginated (Figure 2A \& 2C).

\section{Colour}

In fresh specimen, head and body dark brown dorsal and pectoral fins, except for free rays and posterior half of longest barbels blackish. Anal, pelvic and caudal fins were dark brown and two free pectoral fin rays brown in colour (Figure 2A).

\section{Distribution}

Previously, it's known from East China Sea, Taiwan, Philippines, Indonesia, Andaman Sea, Vanuatu and Fiji (Depth of 259-860 m) and present record of Gulf of Mannar from Bay of Bengal (200-250).

\section{Remark}

Satyrichthys milleri is distinguished from its congeners by having equilateral-triangular rostral projections, four lip and four chin barbells and no anterior directed spines on the upper lateral row of the caudal peduncle.

\section{Discussion}

Satyrichthys is easily distinguished from all congeners in lacking antrorse spines on the posterior bony plates of the lower lateral row and triangular rostral projections. The four (rarely five) lip barbels in S. milleri also differs from the two (rarely one) in S. clavilapis, two in $\mathrm{S}$. longiceps and S. rieffeli and three in S. moluccensis.

In addition, S. milleri is separable from all species of Satyrichthys, except S. laticeps, in having 4 chins. The present record of Satyrichthys milleri was newly invented species previously known from East China Sea, Taiwan, Philippines, Indonesia, Andaman Sea, Vanuatu and Fiji, in depth ranges from $259-860 \mathrm{~m}$ and the nearest known record of Satyrichthys milleri is from the Andaman Sea.

Previously, there was no record from this genus Satyrichthys, this is the first inventory adds to our knowledge of species diversity of Gulf of Mannar from Bay of Bengal, especially southeast coast of India. It is assumed that the southeast coast of India contains as many species as the entire western Indian Ocean because of, the long stretch of coral islands along the Gulf of Mannar and Andaman Nicobar Islands increases the chance of species abundance and richness in the southeast coast of India. During recent years, great numbers of species have been described recorded from the east coast of India. ${ }^{5-12}$

The evident bio-inventory trend shows that in a near future number of fauna species will be documented from Indian waters mainly through exploration of new fishing ground or habitat shift of species from the native regions due to the climate influence migration. The present study is raising the better understanding of the behavior of the deep-sea fishes diversity in the south east coast of India to the researchers.

\section{Acknowledgements}

The authors are grateful to the Director and Scientist-in-Charge, Tuticorin of Central Marine Fisheries Research Institute and the Director, National Bureau of Fish Genetic Resources for the facilities 
to the work. The corresponding author is thankful to Dr. S Lakshmana Senthil, Young Professional II, Central Marine Fisheries Research Institute for his valuable effort for drafting the article.

\section{Conflicts of interest}

None.

\section{References}

1. Kawai T. Phylogenetic systematics of the family Peristediidae (Teleostei: Actinopterygii). Species Diversity. 2008;13:1-34.

2. Kawai T. Revision of the peristediid genus Satyrichthys (Actinopterygii: Teleostei) with the description of a new species. S milleri sp nov Zootaxa. 2013;3635(4):419-438.

3. Miller GC, Richards WJ. Peristediidae. In: Carpenter KE (Ed.), The living marine resources of the Western Central Atlantic. Volume 2: Bony fishes part 1 (Acipenseridae to Grammatidae). FAO Species Identification guide for fishery purposes and American society of ichthyologists and herpetologists special publication No. 5. FAO Rome, USA. 2002;2(5):1278-1285.

4. Kawai T, Imamura H, Nakaya K. Paraheminodus kochiensis Kamohara, 1957 (Teleostei: Peristediidae), a junior synonym of Paraheminodus murrayi (Günther 1880), with a comparison of Paraheminodus murrayi and Paraheminodus laticephalus (Kamohara 1952). Ichthyol Res. 2004;51:73-76.

5. Kannan K, Arumugam G, Sathakkathullah MS, et al. First record of Parapercis clathrata (Perciformes: Pinguipedidae) from Indian waters. Marine Biodiversity Records. 2012;5(54):1-3.
6. Zacharia, PU, Kannan K. First record of Polka-dot ribbonfish Desmodema polystictum (Pisces: Trachipteridae) from Indian waters. Marine Biodiversity Records. 2012;5(8):1-4.

7. Kannan K, Sureshkumar K, Ranjith L, et al. First record of the twostripe goby, Valenciennea helsdingenii (Gobiidae Gobiiformes) from the southeast coast of India. ZooKeys. 2013;323:91-97.

8. Kannan K, Joshi KK, Sajan John, et al. New record of Neobythites multistriatus (Pisces: Ophidiidae) from Bay of Bengal, south-east coast of India. Marine Biodiversity Records. 2013;6:83e.

9. Kannan K, Sajan John, Joshi KK, et al. First record of Neobythites stefanovi (Teleostei: Ophidiidae) from Indian waters. Marine Biodiversity Records. 2013;6:71e.

10. Kannan K, John Sajan, Johnson JA, et al. First record of Striated fusilier Caesio striata Ruppell 1830 (Teleostei: Caesionidae) from Indian waters. Marine Biodiversity Records. 2013;6(106):1-3.

11. Kannan K, Ranjith L, Joshi KK, et al. First record of Grammonus robustus Smith \& Radcliffe 1913 (Ophidiiformes: Bythitidae) from Indian waters. Marine Biodiversity Records. 2014;7(57):1-4.

12. Ranjith L, Kannan K, Suresh Kumar K, et al. Description on Cheilodipterus macrodon (Lacepede 1802) (Perciformes: Apogonidae) from Gulf of Mannar, Southeast coast of India. Thalassas. 2015;31(2):55-60. 